\title{
Evaluation of Physicochemical Properties and Sensory Products of Cocoa Liquor and Dark Chocolate High Polyphenols and Flavanoids
}

\author{
Nur Fitriani UA ${ }^{1, *}$, Muhammad Yusuf ${ }^{2}$ and Pirman ${ }^{2}$ \\ 'Department of Agroindustry, Politeknik Pertanian Negeri Pangkep, Jl. Poros Makassar \\ - Parepare KM. 83 Mandalle, 90655, Pangkep Regency, Indonesia \\ 2Department of Chemical Engineering, Politeknik Negeri Ujung Pandang, Jl. Perintis \\ Kemerdekaan KM. 10 Tamalanrea, 90245, Makassar City, Indonesia
}

Article Type: Article

Article Citation: Nur Fitriani UA, Muhammad Yusuf, Pirman. Evaluation of physicochemical properties and sensory products of cocoa liquor and dark chocolate high polyphenols and flavanoids. Indian Journal of Science and Technology. 2020; 13(07), 840-859. D0l: 10.17485/ijst/2020/v013i07/149883

Received date: January 16, 2020

Accepted date: February 4, 2020

*Author for correspondence:

Nur Fitriani UA nurfitriani.

poltekpangkep@gmail.com 9

Department of Agroindustry, Politeknik

Pertanian Negeri Pangkep, Jl. Poros

Makassar - Parepare KM. 83 Mandalle,

90655, Pangkep Regency, Indonesia

\section{Abstract}

Objectives: This research aims to determine the comparison of cocoa beans without fermentation and cocoa beans fermented dark chocolate products that meet the criteria as a health food based on the content of polyphenols and flavonoids with the aroma and taste that is liked by consumers. Methods/statistical analysis: The parameters tested on dark chocolate and cocoa liquor product are melting properties were determined using DSC (Differential scanning calorimeter), texture (TA-XT Plus Texture Analyzer), Colour lightness was measured using Hunter method (Chromameter), and total levels of polyphenols and flavonoids. In addition, the sensory analysis of aroma and taste using difference from control test methods. Statistical analyses were carried out with Design Expert Stat-Ease Version 11 for response surface methodology (DOE). Panelist data were subjected to analysis of variance (ANOVA) followed by Duncan's Multiple Range, with a significance level of 0.05 . Findings: The results of this study showed that the content of polyphenols and flavonoids on cocoa liquor and the highest dark chocolate respectively amounted to $195.472 \mathrm{mg} / \mathrm{g}$ samples and $79.622 \mathrm{mg} / \mathrm{g}$ samples while the levels of flavonoid respectively amounted to $206.15 \mathrm{mg} / \mathrm{g}$ samples and $113.15 \mathrm{mg} / \mathrm{g}$ samples. Best quality produced from cocoa liquor and dark chocolate (100\% cocoa beans without fermentation) is the viscosity of $10.49 \pm 1.539$ poise and $42.166 \pm 14.936$ poise, texture $5280 \mathrm{~g}$ Force/sec, color lightness 22.03 and 27.42 , melting point $32.17^{\circ} \mathrm{C}$. Based on the organoleptic test, dark chocolate products with a comparison of cocoa beans without fermentation and cocoa beans fermentation 25\%: 75\% have a better aroma and taste and more liked by consumers compared to other products. Applications: Mixing cocoa beans fermentation and without fermentation in the making of dark chocolate can increase the aroma and taste of dark chocolate, so it not only has 
functional properties as a healthy food but also has aroma and flavor that liked by consumers.

Keywords: Cocoa Liquor, Dark Chocolate, Fermentation, Physicochemical Properties, Polyphenols.

\section{Introduction}

Cocoa is an export commodity that contributes to an increase in foreign exchange. The quality of cocoa beans from Indonesia, especially South Sulawesi and West Sulawesi, is below the quality of the cocoa exporting country in the world. The leading cause of low quality of cocoa beans because the fermentation process is not done correctly. The fermentation process can decrease the content of polyphenols in cocoa beans, but the fermentation process is necessary for the formation of aromas and flavors [1-2]. The phytochemical aspects of cocoa beans are well developed into functional chocolate products that are of economic value such as antioxidant tablets, dark choco, late and instant chocolate drink rich in polyphenols. Some of the benefits of polyphenol compounds in cocoa beans are as antidiabetic, antihypertensive, premature anti-aging as well as anti-cancer possibilities [3-4]. In [5] general, cocoa beans produced by farmers are without fermentation so that the quality as a raw material of processed chocolate food products, including the low category. Some of the disadvantages of cocoa beans produced by farmers include low acidity levels, relatively high slaty seed content, and a distinctive flavor of cocoa that is weak because it does not have a compound aroma precursor. The quality of cocoa beans in the chocolate industry is determined by the compound content of polyphenols, aroma, and flavor. The compound content of chocolate aroma and flavor can be obtained through the complete fermentation process of wet cocoa beans before drying [6].

The optimal fermentation process can produce good quality cocoa beans with desired characteristics [7]. Dark chocolate has antioxidant content that can reduce the formation of free radicals in the body so it is good for health. Dark chocolate contains antioxidant components that play a role in controlling Low-Density Lipoprotein (LDL) levels. Choosing dark chocolate with a cacao mass content of $60-80 \%$ will get more nutritional benefits [8-9]. The unfermented cocoa beans contain various compounds of polyphenols, about $60 \%$ of the total polyphenols in cocoa beans (raw cocoa-nuts) are the monomers of flavanol (Epikatekin and Catechins) and pro-Cyanidin oligomers (dimmer and dekamer) with a concentration of vary. The concentration of Epikatekin in cocoa bean extract is estimated at 7-10 times higher than that of cocoa liquor [10-11].

Despite the importance of the chocolate market, there are comparatively few studies, which consider the chemical constituents of the finished chocolate product, which is the product of cocoa beans after fermentation, drying process, roasting, winnowing, alkalization, conching, and finally tempering. The majority focus on analytical methods for determining the geographical origin of unfermented cocoa beans and certain fermentation products. Previous research to look at fatty acid profiles [12], volatile compounds [13], 
Solid State Magic Angle Spinning (MAS) NMR [14], and Fourier Transform Near-Infrared (FT-NIR) [15] are amongst those reported.

This research aims to develop cocoa beans without fermentation as a healthy chocolate product. Cocoa with a high content of polyphenols is a significant health food product of polyphenols. This research is done by producing and evaluating the quality of dark chocolate by varying the amount of concentration of fermented cocoa beans and without fermentation to produce a product rich in polyphenols. Cocoa products obtained will be analyzing the total content of polyphenols and flavonoids, but first conductean d analysis of the total polyphenols and total flavonoids in cocoa liquor before becoming a dark chocolate product. Cocoa liquor is the base of all types of chocolate without any other material added. The purpose of analyzing the content of polyphenols and flavonoids cocoa liquor in advance to compare whether there is a decrease in the levels of polyphenols and flavonoids levels after becoming a dark chocolate product. Mixing cocoa beans fermentation and without fermentation in the making of dark chocolate can increase the aroma and taste of dark chocolate, so it not only has functional properties as a healthy food but also has aroma and flavor that liked by consumers.

\section{Material and Methods}

\subsection{Material}

The chocolate samples evaluated in this study were made and kindly supplied by Cocoa varieties Forastero from Soppeng Regency, South Sulawesi, Indonesia. All samples were made of dark chocolate with lecithin from Sigma-Aldrich (St. Louis, MO), cocoa butter from Mars Symbioscience Company (Makassar, South Sulawesi, Indonesia), and sugar in this order. All chemicals were of analytical grade, hexane (CAS: 110-54-3), sodium carbonate (CAS: 497-19-8) were supplied by Merck Millipore (Burlington, MA), DPPH (D4313, CAS: 1898-66-4) was from Tokyo Chemical Industry (Tokyo, Japan), Folin Ciocalteaue (109001), while aluminum chloride (254134, CAS: 12125-02-9), sodium nitrate (CAS: 7631-99-4), gallic acid (CAS: 149-91-7), and sodium hydroxide (CAS: 131073-2) were from Sigma-Aldrich (St. Louis, MO). All samples were made of fermented cocoa beans and cocoa beans without fermentation in this order. Early stages of this research are the manufacture of cocoa liquor with a variation of cocoa nibs fermentation and without fermentation, then continued with the manufacture of dark chocolate. Enrichment ingredients and their addition to plain cocoa liquor and dark chocolate are listed in Tables 1 and 2.

\subsection{Methods}

\subsubsection{Preparation of Cocoa Liquor Products}

Fermented cocoa beans are roasted in (roasting machine KL Protech Type Number $043.13 \mathrm{P} 033$ capacity $15 \mathrm{~kg}$ ) at $100-105{ }^{\circ} \mathrm{C}$ for $1 \mathrm{~h}$, while the cocoa beans without fermentation are injected at $80{ }^{\circ} \mathrm{C}$ for $40 \mathrm{~min}$ to form a distinctive aroma and flavor of 
chocolate. Minimum roasting machine capacity $8 \mathrm{~kg}$. After the roasting stage is completed, then proceed with cooling up to reach the temperature $40-50{ }^{\circ} \mathrm{C}$. Then samples of cocoa beans were inserted in winnower (nibs separator machine KL Protech Type Number 049.13P043) to separate between nibs and shell (seeds and outer skin). Once separated from the seeds and outer skin, nibs and shells are weighted with a comparison in Table 1. Nibs are then ground using a stone mill (KL Protech Type Number 066.13P063) to destroy nibs that initially shaped coarse solid granular into the cocoa paste (cocoa liquor). Furthermore, cocoa liquor was taken in a ball mill (ball mill mini KL Protech Type Number $041 ., 13 \mathrm{P} 028$ ) which is useful to smooth the still rough cocoa liquor at $50{ }^{\circ} \mathrm{C}$ for 30 h. Cocoa liquor will be analyzed physicochemical content include the analysis of viscosity, the colour, content of polyphenols, and flavonoids.

TABLE 1. Experimental variables and their levels used for response surface methodology (Box Behnken Design) of products cocoa liquor

\begin{tabular}{lccc}
\hline Trial & Code samples & $\begin{array}{c}\text { Fermented cocoa } \\
\text { beans (\%) }\end{array}$ & $\begin{array}{c}\text { Cocoa beans without fermentation } \\
\text { (\%) }\end{array}$ \\
\hline 1 & L1 & 0 & 100 \\
2 & L2 & 25 & 75 \\
3 & L3 & 50 & 50 \\
4 & L4 & 75 & 25 \\
\hline
\end{tabular}

\subsubsection{Preparation of Dark Chocolate Products}

The process of dark chocolate begins with the formulation process in Table 2. Chocolate dough is inserted into the ball mill for conching at a temperature of $50{ }^{\circ} \mathrm{C}$ for $12 \mathrm{~h}$, so obtained the level of smoothness of dough with a particle size close to 20 microns. The molten chocolate was mixed and kept at $25^{\circ} \mathrm{C}$ for $30 \mathrm{~min}$ at a speed of $75 \mathrm{rpm}$. Samples

TABLE 2. Experimental variables and their levels used for response surface methodology (Box Behnken Design) of dark chocolate products

\begin{tabular}{clccccc}
\hline Trial & Code samples & $\begin{array}{c}\text { Sugar } \\
\text { (\%) }\end{array}$ & $\begin{array}{c}\text { Cocoa } \\
\text { liquor (\%) }\end{array}$ & $\begin{array}{c}\text { Lecithin } \\
\text { (\%) }\end{array}$ & $\begin{array}{c}\text { Cocoa butter } \\
\text { (\%) }\end{array}$ & $\begin{array}{c}\text { Vanilla } \\
\text { (\%) }\end{array}$ \\
\hline 1 & $\begin{array}{l}\text { D1 (100\% cocoa beans } \\
\text { without fermentation) }\end{array}$ & 45.6 & 45.3 & 0.5 & 8.5 & 0.1 \\
2 & $\begin{array}{l}\text { D2 (75\% cocoa beans } \\
\text { without fermentation: } \\
\text { 25\% fermented cocoa } \\
\text { beans) }\end{array}$ & 45.6 & 45.3 & 0.5 & 8.5 & 0.1 \\
\hline $\begin{array}{l}\text { D3 }(50 \% \text { cocoa beans } \\
\text { without fermentation: }\end{array}$ & 45.6 & 45.3 & 0.5 & 8.5 & 0.1 \\
\hline $\begin{array}{l}50 \% \text { fermented cocoa } \\
\text { beans) } \\
\text { D4 }(25 \% \text { cocoa beans } \\
\text { without fermentation: } \\
75 \% \text { fermented cocoa } \\
\text { beans) }\end{array}$ & 45.6 & 45.3 & 0.5 & & \\
\hline
\end{tabular}


were then quenched to $25^{\circ} \mathrm{C}$ and held at that temperature level for $10 \mathrm{~min}$, and then the samples were heated to $30^{\circ} \mathrm{C}$ and kept at that temperature for $10 \mathrm{~min}$. Tempering is the process of melting the chocolate, precisely at the temperature required by brown fats to form a perfect crystallization or freezing, so that the results are shiny and dried. Chocolate dough in shape for $15-25 \mathrm{~min}$ with a mixed temperature of $30^{\circ} \mathrm{C}$. Throughout the entire conventional tempering process, all the samples were stirred automatically. Finally, after depositing the freshly tempered chocolates $\left(15^{\circ} \mathrm{C}\right)$, they were stored at $5-15^{\circ} \mathrm{C}$ and $45 \%$ $\mathrm{RH}$ for $24 \mathrm{~h}$ to improve crystal growth. Then samples were maintained at $5{ }^{\circ} \mathrm{C}$ until the analyses.

\subsubsection{Total Phenolic Assay}

The total phenolic content of dark chocolate and cocoa liquor was determined by using the Folin-Ciocalteu assay [16]. An aliquot ( $1 \mathrm{~g})$ of extracts or standard solution of gallic acid $(2,4,6,8,10$, and $12 \mathrm{ppm})$ was added to a $25 \mathrm{ml}$ volumetric flask containing $9 \mathrm{ml}$ of distilled deionized water $\left(\mathrm{ddH}_{2} \mathrm{O}\right)$. A reagent blank using $\mathrm{ddH}_{2} \mathrm{O}$ was prepared. One milliliter of Folin-Ciocalteu phenol reagent was added to the mixture and shaken. After 5 min, $10 \mathrm{ml}$ of $7 \% \mathrm{Na}_{2} \mathrm{CO}_{3}$ solution was added to the mixture. The solution was diluted to volume $(25 \mathrm{ml})$ with $\mathrm{ddH}_{2} \mathrm{O}$ and mixed. After incubation for $90 \mathrm{~min}$ at room temperature, the absorbance against prepared reagent blank was determined at $750 \mathrm{~nm}$ with a UV-Vis Spectrophotometer Lambda 5. The total phenolic content of dark chocolate and cocoa liquor was expressed as $\mathrm{mg}$ gallic acid equivalents (GAE)/100 g fresh weight. All samples were analyzed in duplicates.

\subsubsection{Total Flavonoid Assay}

Total flavonoid content was measured by the aluminum chloride colorimetric assay. An aliquot $(0.5 \mathrm{ml})$ of extracts or standard solution of catechin $(5,10,15,20,25,30,35,40,45$, 50 , and $55 \mathrm{ppm}$ ) was added to $10 \mathrm{ml}$ volumetric flask containing $4 \mathrm{ml}$ of $\mathrm{ddH}_{2} \mathrm{O}$. To the flask was added $0.3 \mathrm{ml} 5 \% \mathrm{NaNO}_{2}$. After $5 \mathrm{~min}, 0.3 \mathrm{ml} 10 \% \mathrm{AlCl}_{3}$ was added. At $6 \mathrm{~min}, 2$ $\mathrm{ml} 1 \mathrm{M} \mathrm{NaOH}$ was added, and the total volume was made up to $10 \mathrm{ml}$ with $\mathrm{ddH}_{2} \mathrm{O}$. The solution was mixed well, and the observance was measured against prepared reagent blank at $510 \mathrm{~nm}$. The total flavonoid content of dark chocolate and cocoa liquor was expressed as $\mathrm{mg}$ catechin equivalents (CE)/100 g fresh mass. Samples were analyzed in duplicates.

\subsubsection{Colour Analysis of Food Products}

Colour lightness of the dark chocolate and cocoa liquor samples was measured using Hunter method (as L, a, and b value) in triplicate with a Minolta Chroma CR-400 (Minolta Co, Osaka, Japan). The parameter of the value $\mathrm{L}$, $\mathrm{a}$, and $\mathrm{b}$ sample will be visible, where the value of $L$ is the lightness, the value $(+)$ on a indicates the red color and the value $(-)$ on a show green color, the value $(+)$ in the $b$ indicates the yellow color and the value $(-)$ on the $b$ indicates the blue color. It is then measured on the chart to know the color specifications [17]. 


\subsubsection{Determination of Viscosity}

The viscosity of the melted dark chocolate and cocoa liquor samples was obtained by fitting shear stress and shear rate values using the Casson fitting model, Using a Viscometer (DV1 Digital Viscometer Brookfield). The spindle tool used is the 64 spindles, at a speed of $10 \mathrm{rpm}$ with a temperature of $50^{\circ} \mathrm{C}$ for $1 \mathrm{~min}$. Friction between the spindle surface and the sample fluid determines the viscosity level [18].

\subsubsection{Determination of Melting Properties}

Melting properties of dark chocolate and cocoa liquor samples were determined using differential scanning calorimeter (DSC) DSC-60 Plus Series Shimadzu for this aim. Samples (approximately $4 \mathrm{mg}$ ) were loaded into $40 \mathrm{ml}$ capacity pans and sealed with hermetic lid using a sample press. The corresponding parameters representing melting profile of the samples, onset temperature ( $T_{\text {onset }}$ where melting of the samples started), peak temperature ( $T_{\text {peak }}$ where the highest rate of the melting was observed), end temperature $\left(T_{\text {end }}\right.$ where the samples melted completely) and $\Delta H$ (energy required for complete melting of the samples) were calculated from the thermograms obtained after heating the pans from 23 to $50{ }^{\circ} \mathrm{C}$ at $3^{\circ} \mathrm{C} / \mathrm{min}$ heating rate performed by $\mathrm{N}_{2}$ stream [19].

\subsubsection{Texture Profile Analysis (TPA) of Dark Chocolate and Cocoa Liquor}

Determination of textural properties of molten chocolates was evaluated using a TA-XT Plus Texture Analyzer (Stable Micro Systems, Godalming, Surrey, England) with back extrusion rig and a $35 \mathrm{~mm}$ diameter compression disk attached to an extension bar using $50 \mathrm{~kg}$ load cell. Samples melted at $50^{\circ} \mathrm{C}$ for 75 min were quickly transferred to a standard back extrusion container (50 mm diameter) and work done in back extruding $100 \mathrm{ml}$ chocolate determined to measure force in compression. Two replications per sampletest of $5.0 \mathrm{~mm} / \mathrm{s}$ above sample surface, penetrating $30 \mathrm{~mm}$, then returning to the start position. Mean values were used to obtain a force-time curve (XT.RA Dimension, Exponent 32 software; Stable MicroSystems) calculating as texture parameters: 1 . Firmness = maximum compression force in extrusion thrust into the sample $(g)$; 2 . Index of viscosity = area of curve negative region during probe withdrawal $(g s)$. The hardness of solid tempered dark chocolate and cocoa liquor was measured using the Texture Analyzer with a penetration probe (needle $\mathrm{P} / 2$ ) attached to an extension bar, a $50 \mathrm{~kg}$ load, cell and a platform. Maximum penetration force through a sample $(80 £ 20 \mathrm{~mm}$, depth $8 \mathrm{~mm}$ ) was determined with eight replications at a speed of $1.0 \mathrm{~mm} / \mathrm{s}$, test of $2.0 \mathrm{~mm} / \mathrm{s}$, post-speed of $10.0 \mathrm{~mm} / \mathrm{s}$, penetrating $5 \mathrm{~mm}$ at $20{ }^{\circ} \mathrm{C}$, converting mean values into hardness data using XT.RA Dimension, Exponent 32 software (Stable Micro Systems, Godalming, UK) [20-21].

\subsubsection{Sensory Evaluation of Dark Chocolate}

We are using sensory analysis methods, Difference from Control Test. The panelist is presented with 1 (one) Control sample (R) and 7 (seven) samples as a test, and 1 Control sample is treated as a blind control test sample. A panel of skilled evaluators assessed the 
samples with a 9-point scale (1- Very, very good taste of R, 2- Very better taste of R, 3flavors better than R, 4- Taste somewhat better than R, 5- Taste as good as R, 6- Taste somewhat worse than R, 7- Taste worse than R, 8- Taste very worse than R, and 9- Awful taste of R), by 31 trained panelists selected from post-graduate students and staff of the Department Chemical Engineering, Politeknik Negeri Ujung Pandang.

\subsubsection{Statistical Analysis}

Statistical analyses were carried out with Design Expert Stat-Ease Version 11 (StatEaseInstitute Inc Minneapolis., 2019) for response surface methodology (DOE). Panelist data were subjected to analysis of variance (ANOVA) followed by Duncan's Multiple Range, with a significance level of 0.05 . All analysis was performed using the statistical program Statistical Package for the Social Sciences (SPSS) version 17.0 (International Business Machines Corporation, New York, NY).

\section{Results and Discussion}

\subsection{Identification Total Phenolic and Flavonoid}

The products in this research are cocoa liquor and dark chocolate made from cocoa beans with a variation of the number of cocoa beans without fermentation and fermented cocoa beans. Dark chocolate is a product that is rich in polyphenols and flavonoids with cocoa mass (liquor), about 70\%. Variation of the number of cocoa beans without more significant fermentation of fermented cocoa beans. Cocoa liquor samples produced from $100 \%$ of cocoa beans without fermentation show the highest levels of high polyphenols and flavonoid, while cocoa liquor samples from $25 \%$ cocoa beans without fermentation and $75 \%$ of fermented cocoa beans demonstrate the total levels of polyphenols, due to the fermentation process that can lower the levels of polyphenols and flavonoid in the product. In cocoa liquor products, sample L1 with the highest content of polyphenols and flavanoids of $195.472 \mathrm{mg} / \mathrm{g}$ samples and $206.15 \mathrm{mg} / \mathrm{g}$ samples (Figure 1). While on the sample, dark chocolate code D1 total content of polyphenols and the highest flavonoids of $79.622 \mathrm{mg} / \mathrm{g}$ samples and $113.15 \mathrm{mg} / \mathrm{g}$ samples (Figure 2). The total levels of polyphenols and flavonoids in dark chocolate samples (D1-D4 code) are reduced by increasing the number of fermented cocoa beans. The fermentation process can decrease the content of polyphenols and flavonoids, which are directly proportional to the increasing number of fermented cocoa beans [22-23].

The decrease in the content of polyphenols during fermentation is caused by the diffusion of polyphenols that come out of the seed chip. During cocoa beans fermentation, polyphenols are subjected to biochemical modifications through oxidation and polymerization and binding with protein, hence decreasing their solubility and astringency effect. At the same time, anthocyanins are hydrolyzed to produce anthocyanidins, galactose andarabinose; beside dimerisation of leucocyanidins and exudation of the flavonoids from the bean. Subsequently, during drying, the amount of polyphenols are substantially reduced mainly by enzymatic browning [24-25]. Polyphenols are oxidized by polyphenols 

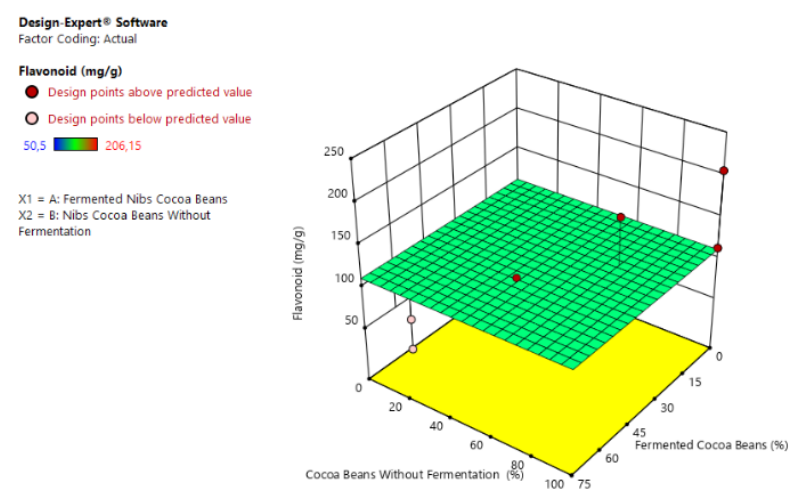

(a)
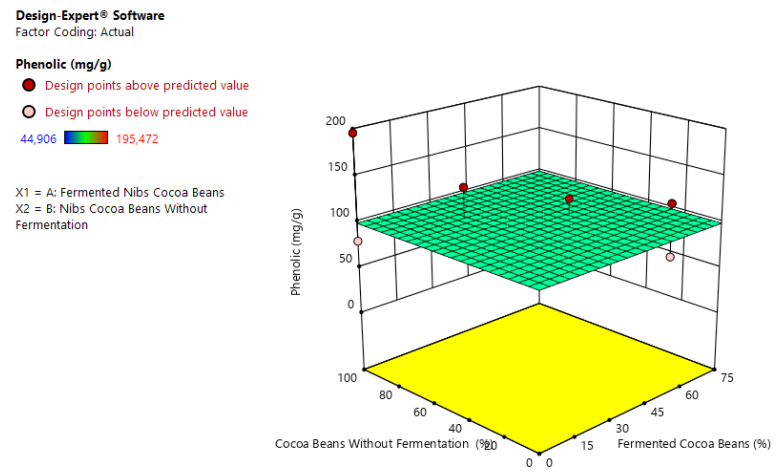

(b)

FIGURE 1. Response surface plot for the effect of process cocoa beans without fermentation and fermented cocoa beans (a), flavonoid, and (b) phenolic of cocoa liquor.

oxidase forming quinone and diquinon followed by polymerization and the formation of insoluble pigment compounds with high molecular weights. In addition, reactions with proteins also contribute to the decrease in the total content of polyphenols. This research shows that the total levels of polyphenols and flavonoids in cocoa liquor are higher than after being dark chocolate products. This is due to the process of processing from cocoa liquor to dark chocolate has passed several processes of heating (conching) so as to reduce levels of polyphenols and flavonoids. The more stages of processing involving the heating process, the more content of the loss of polyphenols and flavonoids [26-27]. Dark chocolate products produced in this research have high levels of polyphenols and flavonoids so that it can meet the criteria as a health food based on the content of polyphenols and Flavonoidnya. Dark chocolate products can increase the concentration of high-density lipoprotein (HDL) cholesterol, thereby lowering a person to be exposed to cardiovascular diseases. The total phenolic content of the beans and cocoa products is very influenced by the interaction of genetic factors with their surroundings. In the period before the harvest (pre-harvest) total phenolic content influenced by the interaction of genetic 

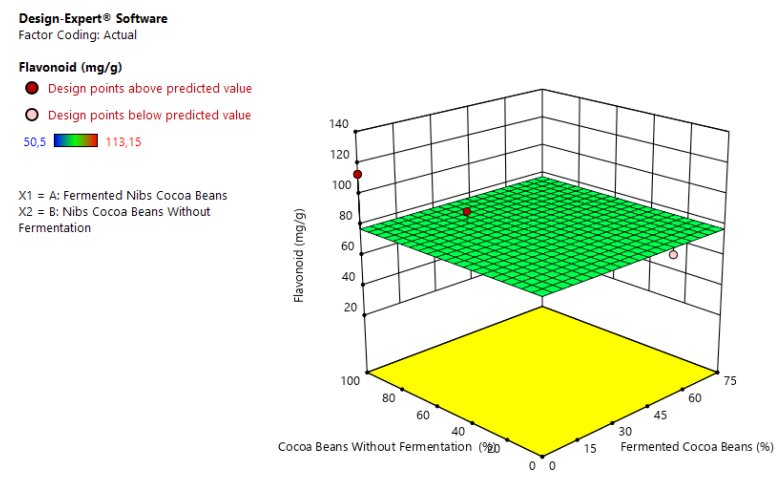

(a)
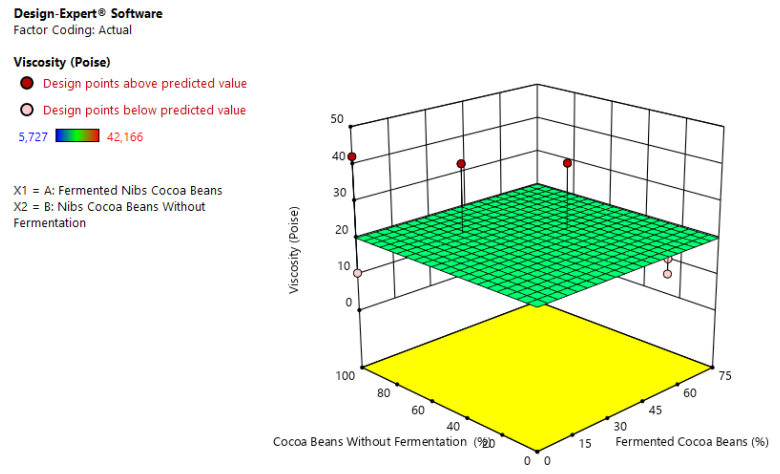

(b)

FIGURE 2. Response surface plot for the effect of process cocoa beans without fermentation and fermented cocoa beans (a), flavonoid, and (b) phenolic of dark chocolate.

factors (genotype/varieties/clone) with environmental factors biophysics oragronomist (aquaculture). Later in the period of post-harvest, the components of the post-harvest interact each other with processing factors (the process of fruit storage, fermentation, drying, and roasting) to influence polyphenol content [28].

\subsection{Color Analysis of Food Products}

Color cocoa liquor and milk chocolate products are defined with the color system Munsell $(\mathrm{L}, \mathrm{a}, \mathrm{b})$. The value $\mathrm{L}^{*}, \mathrm{a}^{*}$, and $\mathrm{b}^{*}$ is calculated using the Chromameter instrument Minolta CR-400. The basic principle of this tool is the interaction between the diffuse light energy and the atom or molecule of the object being analyzed. In the Munsell Color System, where L indicates the lightness that has a value range of 0 (dark/black) to 100 (light/white), $\mathrm{a}$ and $\mathrm{b}$ indicate the chroma coordinates, where a indicates the color green (a negative) to red (a positive), $b$ for the color blue ( $b$ negative) to yellow (b positive). HUE values indicate the actual sample color, while the $C$ value indicates the color, sharpness of the sample [29]. Colour analysis results with the Munsell method can be seen in Table 3. 
TABLE 3. Result color measurement of cocoa liquor and dark chocolate product with Chromameter Minolta CR-400

\begin{tabular}{|c|c|c|c|c|c|c|c|}
\hline \multirow{2}{*}{ No } & \multirow{2}{*}{ Sample } & \multicolumn{5}{|c|}{ Value } & \multirow{2}{*}{ Color } \\
\hline & & $\mathbf{L}^{*}$ & $a^{*}$ & b* & Hue & C & \\
\hline 1 & L1 & 22.03 & +3.63 & +3.11 & 71 & 11.42 & Orange (YR) \\
\hline 2 & L2 & 23.09 & +4.34 & +5.20 & 88 & 22.93 & Orange (YR) \\
\hline 3 & L3 & 24.73 & +4.56 & 4.69 & 80 & 21.39 & Orange (YR) \\
\hline 4 & $\mathrm{~L} 4$ & 27.89 & +5.91 & +5.50 & 75 & 32.58 & Orange (YR) \\
\hline 5 & D1 & 27.42 & +7.47 & +5.93 & 67 & 45.48 & Orange (YR) \\
\hline 6 & D2 & 28.65 & +6.27 & +7.35 & 86 & 46.66 & Orange (YR) \\
\hline 7 & D3 & 29.91 & +7.94 & +6.92 & 72 & 55.46 & Orange (YR) \\
\hline 8 & D4 & 30.42 & +9.38 & +11.46 & 88 & 109.65 & Orange (YR) \\
\hline
\end{tabular}

Legend: Sample L1/D1 (100\% cocoa beans without fermentation), sample L2/D2 (25\% of fermented cocoa beans: 75\% without fermentation), sample L3/D3 (50\% of fermented cocoa beans: 50\% of without fermentation), sample L4/D4 (75\% of fermented cocoa beans: $25 \%$ of without fermentation).

The values of $\mathrm{L}^{*}, \mathrm{a}^{*}$, and $\mathrm{b}^{*}$ cocoa liquor samples (codes L1, L2, L3, and L4) that the value of L (lightness) samples of L1, L2, L3, and L4, respectively were 22.03, 23.09, 24.73, and 27.89. The decrease in the $L$ value causes the lightness of the cocoa liquor sample to be darker. Furthermore, the value of $\mathrm{a}^{*}$ and $\mathrm{b}^{*}$ cocoa liquor samples each increased from +3.63 (L1) to +5.91 (L4) and from +3.11 to +5.50 . Oxidation of the epicatechin compounds in the seeds during the fermentation and drying process determines the characteristic of brown colour in the fermented cocoa beans as the raw material of chocolate. Polyphenols content contributes to bitterness, astringency, color $\left(a^{*}\right.$ and $\left.b^{\star}\right)$, flavor, smell, and oxidative stability [30-31]. Fermented cocoa beans have a more brown colour, can provide better colour and aroma when compared to cocoa without fermentation. The intensity of cocoa color during the fermentation process is increased compared to the cocoa beans without fermentation that produce a darker color, but between the sample L1 until the sample L4 and the sample D1 until the sample D4 color intensity is not much different (smaller differences). Some factors that can affect the product colour are the composition of raw materials and production processes, where fermented cocoa beans will change the characteristics of seeds through the chemical reaction process.

\subsection{Viscosity}

The manufacture of chocolate products begins with grinding nibs into cocoa liquor as a semi-productive in the liquid phase. One parameter that determines the characteristics of chocolate products is the viscosity of cocoa liquor. Figure 3 shows the response surface plot on the viscosity value of cocoa liquor and dark chocolate resulting from a comparison of the fermented cocoa nibs composition and without fermentation.Cocoa liquor viscosity value is directly proportional to the concentration variation of each sample. The L1 sample has the highest viscosity value of $10.49 \pm 1.539$ poises and the lowest of the L4 sample is $5.727 \pm 0.072$ poises. From a sample L1 to a sample of L4, the viscosity value began to decline with a decrease in the concentration of cocoa beans without fermentation. At the dark chocolate, the highest viscosity value of the sample D1 is $42.166 \pm 14.396$ poise and 

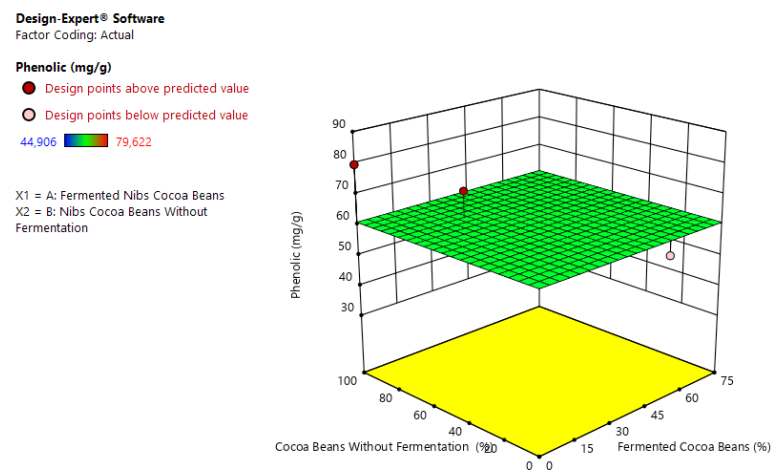

(a)
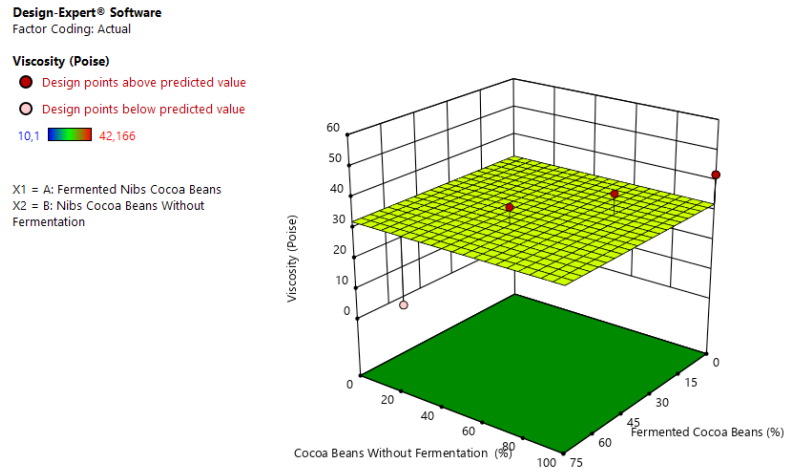

(b)

FIGURE 3. The response surface plot for the effect of process cocoa beans without fermentation and fermented cocoa beans on the viscosity (a), cocoa liquor, and (b) dark chocolate.

the lowest in the D4 sample is $10.1 \pm 1.414$ poises. Similar to the sample L1 up to the L4 sample, its viscosity value from the sample D1 until the D4 sample began to decline with a decrease in the amount of cocoa concentration without fermentation. This is due to decreased seeds without fermentation occurs a decrease in the amount of fat so that the viscosity value is low (Table 4 ).

Cocoa beans without fermentation have a fat content that is still less than fermented cocoa beans. Decreasing the number of cocoa beans without fermentation causes a decrease in the amount of fat, thereby increasing the viscosity value. The phospholipid content in cocoa butter affects viscosity. The viscosity is reduced by the rise of phospholipids in cocoa butter. Coarse fat content (crude fat) fermented cocoa beans amount $22 \pm 0.10 \%$ and cocoa beans without fermentation of $6 \pm 0.07 \%$ [32].

Fermented cocoa beans will decrease the content of fat, raw materials such as proteins, polyphenol,s and carbohydrates that decompose so that the relative fat levels will increase [33-34]. Cocoa fats can decrease the viscosity value of chocolate products, the increase in fat content in the product will reduce its viscosity value [35]. Processing of the product into 
TABLE 4. The viscosity of cocoa liquor and dark chocolate

\begin{tabular}{lcc}
\hline Products & Sample & Viscosity value (Poise) \\
\hline & L1 & $10.49 \pm 1.539$ \\
Cocoa liquor & L2 & $9.49 \pm 1.414$ \\
& L3 & $6.655 \pm 0.068$ \\
L4 & $5.727 \pm 0.072$ \\
Dark chocolate & D1 & $42.166 \pm 14.936$ \\
& D2 & $39.133 \pm 14.068$ \\
& D3 & $38.15 \pm 16.062$ \\
& D4 & $10.1 \pm 1.414$ \\
\hline
\end{tabular}

Legend: Sample L1/D1 (100\% cocoa beans without fermentation), sample L2/D2 (25\% of fermented cocoa beans: $75 \%$ without fermentation), sample L3/D3 (50\% of fermented cocoa beans: 50\% of without fermentation), sample L4/D4 (75\% of fermented cocoa beans: $25 \%$ of without fermentation).

a dark chocolate viscosity value will increase due to the addition of different ingredients (lecithin, sugar, and cocoa butter) so that the viscosity can increase. Viscosity can affect the material added. The more types of materials added to the chocolate the higher the viscosity. The viscosity of a fluid is a trait that indicates large and small prisoners in the fluid against friction. Friction between spindle surfaces on a device with fluid determines the viscosity of the fluid level [36]. Flavor parameters of chocolate products in the mouth one of them is influenced by viscosity. Some research suggests that high viscosity chocolate products have amouth-feel pasty and are related to particle size, composition, and process strategy. Measurement of physical product properties aims to maintain quality control of necessary materials and processing processes [37-38].

\subsection{Determination of Melting Properties}

DSC is a thermal analysis used to measure the difference in heat flow between samples and references measured as temperature functions [20]. The main application of the DSC is to study phase transitions, such as smelting, glass transitions, or exothermic decomposition. This transition involves changes in energy or changes in heat capacity that the DSC can detect with great sensitivity. Based on Figures 4-5, samples D1 shows the endothermic peak process with a melting point of $32.17^{\circ} \mathrm{C}$. This process shows that cocoa butter melted perfectly. Cocoa butter (cocoa fat) is a mixture of triglycerides that are composed of a POST (Palmitate-oleate-stearate) of $38.0 \%-43.8 \%$, POP (Palmitate-oleate-stearate) of $16.8 \%-19.0 \%$ and SOS (Stearate-oleate-stearate) of $22.8 \%-30 \%$ melted perfectly at the temperature of $32-35^{\circ} \mathrm{C}$. The high melting point occurs in the temperature of $35^{\circ} \mathrm{C}$, where the chocolate will melt completely. The initial melting point is the temperature when the first drip occurs fat, while the final melting point is the temperature when the whole fat has been melted perfected [35]. The lowest melting point on the $\mathrm{D} 4$ sample of $31.73{ }^{\circ} \mathrm{C}$ and the highest melting point is on the D2 (Figures 6-7) sample of $32.68^{\circ} \mathrm{C}$. The melting point of each sample indicates a relatively small difference.

Storage conditions and tempering process can change the crystal structure in cocoa butter and affect the melting point. The tempering process is a process to regulate the bond 


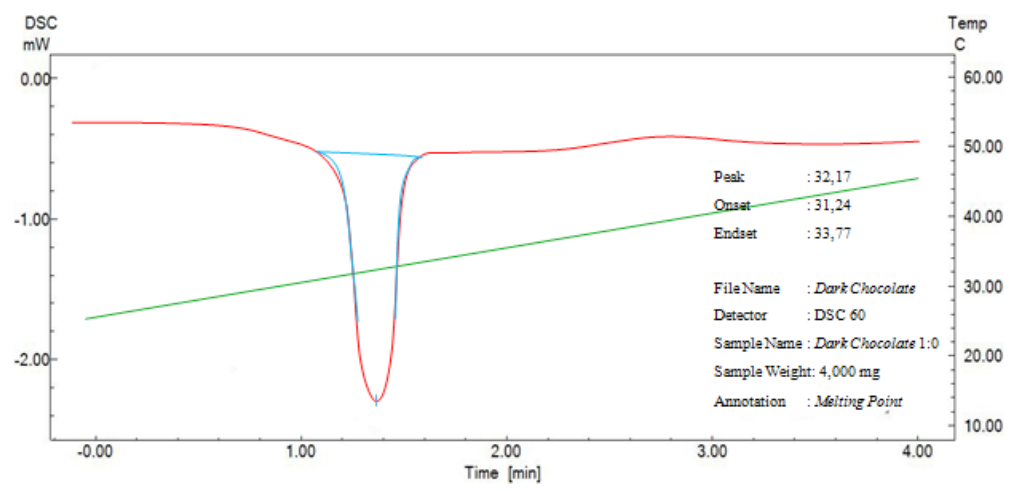

FIGURE 4. DSC curve sample D1 (100\% cocoa beans without fermentation).

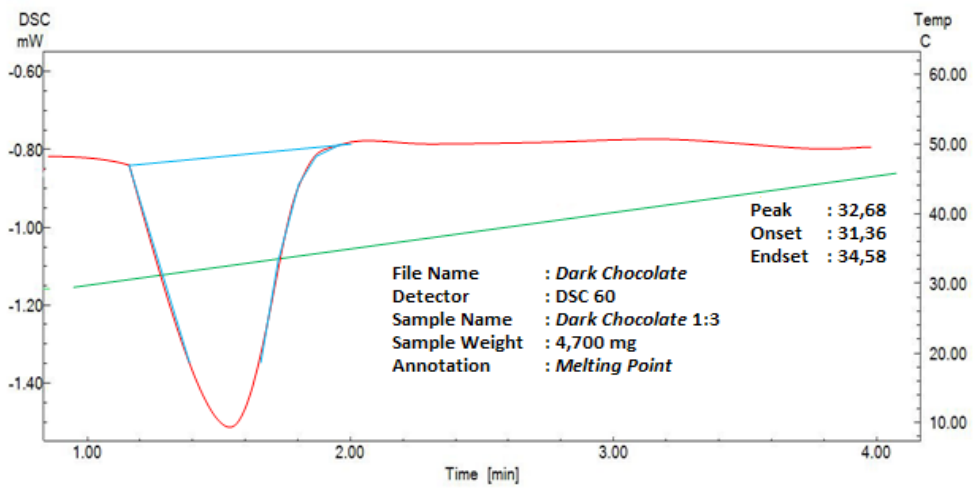

FIGURE 5. DSC curve sample D2 (cocoa beans without fermentation 75\%: cocoa beans fermentation 25\%).

of crystals in cocoa fat. After the heating process, the bonding structure of each of them regardless corresponds to the type of fatty crystals and forms the bonds of polymorphism $\alpha, \beta$, and $\beta^{\prime}$. The form of $\beta$ is the most desirable form by the cocoa industry because it has a melting point of $29.5-36^{\circ} \mathrm{C}$ and is most stable at room temperature. The crystals in cocoa can form $\gamma, \alpha, \beta$, and $\beta$ with a melting point is the same as $16.9-18^{\circ} \mathrm{C}, 22-24^{\circ} \mathrm{C}, 24-29.4^{\circ} \mathrm{C}$ and $29.5-36^{\circ} \mathrm{C}$. In the sample $\mathrm{D} 1$ until the $\mathrm{D} 4$ sample, the melting point ranges from 31.73 ${ }^{\circ} \mathrm{C}-32.68{ }^{\circ} \mathrm{C}$. From the melting point range, a sample D1 to a sample of D4 is included in the type of fatty crystals of a $\beta$ polymorphism bond because it has a stable $29.5-36^{\circ} \mathrm{C}$ melting point at room temperature. The cocoa butter in chocolate products has six different crystal structure [36-39]. Table 5 shows a melting point for six chocolate structures dark chocolate products (sample code D1, D2, D3, and D4) show a type V crystal structure with good texture and stability influences. Based on research conducted by Rothkopf \& Danzl (2015), the filling lipids can function as an activator for diffusion processes with the formation of fat bloom as a consequence. Filling lipids can merge with chocolate during production or storage. However, in most studies concerning crystallization or migration cocoa butter and hazelnut oil were analyzed, investigations on chocolate are rare. To cover 


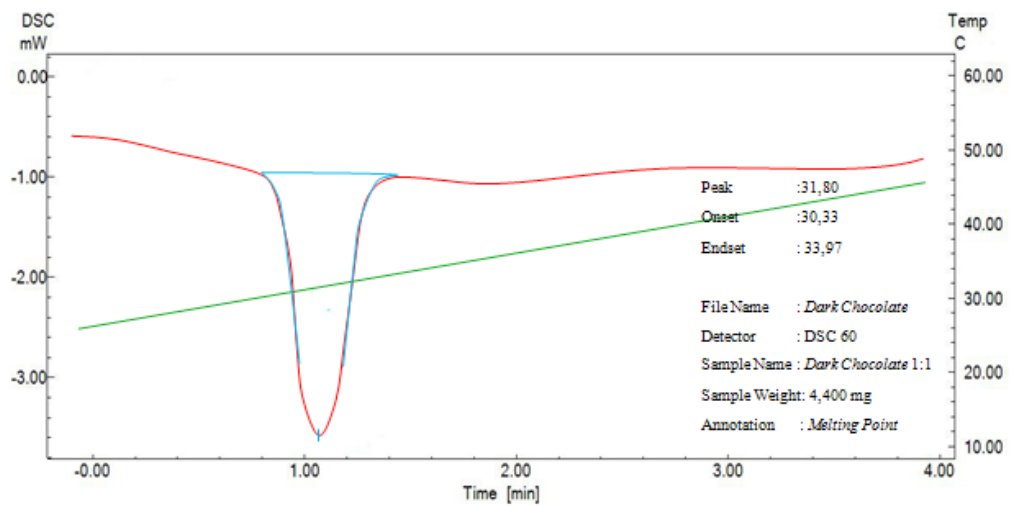

FIGURE 6. DSC curve sample D2 (cocoa beans without fermentation 50\%: cocoa beans fermentation 50\%).

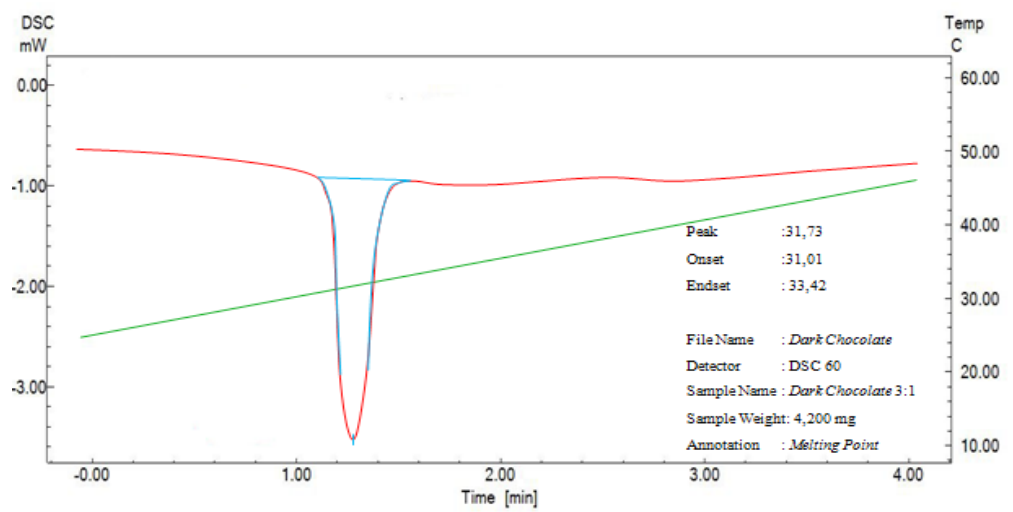

FIGURE 7. DSC curve sample D4 (cocoa beans without fermentation 25\%: cocoa beans without fermentation 75\%).

TABLE 5. Chocolate crystal type

\begin{tabular}{lcl}
\hline Crystal & Melting point & Description \\
\hline I & $13.1^{\circ} \mathrm{C}$ & Soft, Crumbly, melts too easily \\
II & $17.1^{\circ} \mathrm{C}$ & Soft, Crumbly, melts too easily \\
III & $22.4^{\circ} \mathrm{C}$ & The firm, poor snap, melts too easily \\
IV & $26.4^{\circ} \mathrm{C}$ & The firm, good snap, melts too easily \\
V & $30.7{ }^{\circ} \mathrm{C}$ & The glossy, firm, best snap, melts near body temperature \\
VI & $33.8^{\circ} \mathrm{C}$ & Hard, takes weeks to form \\
\hline
\end{tabular}

a broad variety of fillings, dark chocolate was blended with hazelnut oil, butterfat, and coconut oil and crystallization was analyzed. All investigated lipids reduced the solid fat content to the same extend. However, crystallization behavior of the blended samples differed. Hazelnut oil accelerated crystallization rate and did not affect crystallization time, while butterfat reduced crystallization rate and time. The effect of coconut oil addition 
was in between those of hazelnut oil and butterfat. Nucleation and crystal growth rate, which affect the crystallization speed, have been shown to be affected by the type of filling lipid. Additionally, there is evidence that crystal transformation during crystallization is also affected by filling lipids. @ 2015 WILEY-VCH Verlag GmbH", "author":[\{“droppingparticle":"”, “family":"Rothkopf”, “given”:"Isabell”, "non-dropping-particle”:"”, "parsenames":false, "suffix":"”'\}, \{“dropping-particle":"', “family":"Danzl”, "given”:"Wolfgang", "non-dropping-particle":"', "parse-names":false, "suffix":"'\}], "container-title":"European Journal of Lipid Science and Technology", “id”:"“TEM-1", “issued”:\{“date-parts":[[“2015”]]\}, "title": "Changes in chocolate crystallization are influenced by type and amount of introduced filling lipids", "type":"article-journal"], "uris":["http://www.mendeley.com/ documents/?uuid=6ea9e1d4-f3f9-449a-92ea-98a36d190904"]\}], "mendeley": ‘ “formatted Citation":" [40]", "manualFormatting":"Rothkopf \& Danzl (2015, shows that high-quality chocolate, in general, has a V crystal type with a rather harsh texture. The V and VI crystal structures with a more tightly-structured arrangement cause a sharp texture difference.

\subsection{Texture Measurements}

The measurement of dark chocolate texture using puncture method, probe is pressed by a constant style magnitude to penetrate the sample penetrating at a certain depth and time as well as in a predefined condition so that it can be known hardness value from dark chocolate. Sample D3 has the highest hardness value of $7820.533 \mathrm{~g}$ force/sec later in order on the sample D4 and D1, which is $7481.671 \mathrm{~g}$ force $/ \mathrm{sec}$ and $5280.287 \mathrm{~g}$ force $/ \mathrm{sec}$. Lowest hardness value measurements in the D2 sample of $4613.903 \mathrm{~g}$ force/sec (Figure 8). The texture quality of chocolate products depends on the melting point and crystallization of cocoa butter used [40-41]. The chocolate texture is strongly influenced by the intrinsic hardness of cocoa fats [42]. In the sample, D3 produces the highest hardness value compared to other samples because of the melting point value of $31.80^{\circ} \mathrm{C}$. the crystal structure between the temperature of $30.7^{\circ} \mathrm{C}-33.8^{\circ} \mathrm{C}$ with a more tightly arrangement led to a harsh texture difference. The texture is a common trait that encompasses the biological, mechanical, and sensory properties of foodstuffs to taste when consumed in the mouth. Good dark chocolate product must have a smooth texture that can melt softly and gently in the mouth. Mixing and stirring process in a long time can reduce the size of the chocolate particles and this affects the texture of chocolate. The large size of sugar particles is one of the causes of sandy and not a smooth texture. Therefore, we need refining or conching treatment process in a long time to reduce the size of the particles to the produced smooth texture of chocolate.

\subsection{Sensory Evaluation of Dark Chocolate}

Sensory testing systems are developed based on assessment objectives. Test the difference of control applied in the testing of dark chocolate products produced. Products comparator (control) used is a commercial dark chocolate product that already has a market. Product of dark chocolate research results compared with the control product to determine the intensity of difference in various aspects of the assessment. Dark chocolate has a variety of distinctive flavor and aroma that can be scanned through sensory assessment. Organoleptic 

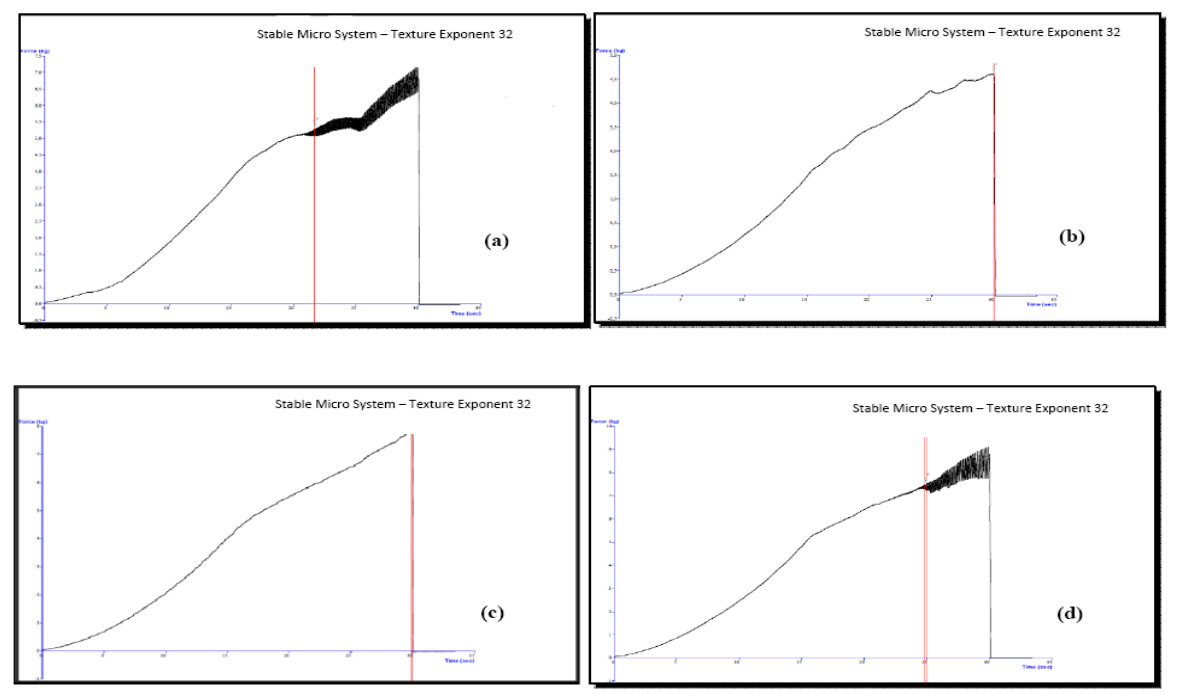

FIGURE 8. Graphic hardness of dark chocolate products (a) $100 \%$ cocoa beans without fermentation, (b) $25 \%$ of fermented cocoa beans: $75 \%$ without fermentation, (c) $50 \%$ of fermented cocoa beans: $50 \%$ of without fermentation, and (d) $75 \%$ of fermented cocoa beans: $25 \%$ of without fermentation.

test of dark chocolate products includes flavor and aroma parameters using a difference of control test methods to find out a difference between one or more samples with control and estimate how much difference between control.

Organoleptic testing of dark chocolate products (Table 6), sample 123 obtained the highest mean value of the assessment panelist against the dark chocolate flavor in 249 . From the value of the mean, then analyzed using analysis of variance (ANOVA). Results obtained from ANOVA, F count, is higher than the F-value of the table so that it continues with the analysis of the redundant's multiple tests to determine which samples are different.

The method of Duncan's multiple range test can be concluded that samples 132, 213, 312,123 , and 231 which is a product of dark chocolate with a variation of the concentration of cocoa beans without fermentation and fermented cocoa beans have different flavor with control products in which the comparison product (control) used is the commercial dark chocolate products sold in the market. $5 \%$ of all samples are different from control products

TABLE 6. Mean value dark chocolate

\begin{tabular}{cc}
\hline Formulation dark chocolate & Mean \\
\hline 132 & 8.032 \\
213 & 7.225 \\
312 & 4.838 \\
123 & 7.193 \\
231 & 6.161 \\
\hline
\end{tabular}

Legend: Sample 132 (100\% cocoa beans without fermentation), sample 213 (25\% of fermented cocoa beans: $75 \%$ without fermentation), sample 312 ( $50 \%$ of fermented cocoa beans: $50 \%$ of without fermentation), 123 ( $75 \%$ of fermented cocoa beans: $25 \%$ of without fermentation), sample 231 (dark chocolate commercial products). 
or dark chocolate with varying concentrations of cocoa beans without fermentation and fermented cocoa beans (100\%, 75\%:25\%, 50\%:50\%, 25\%:75\%) Produce noticeable flavor differences with control products. Panelist chose sample 123 with the highest LSR value of cocoa beans without fermentation 25\%: fermented cocoa beans $75 \%$ as flavor better than other samples. Organoleptic test results showed that the essential ingredients ofchocolate are alkalized cocoa mass, cocoa powder or cocoa butter,sugars, lecithin, and, in the case of milk chocolate, milk powderor crumbs. Chemical compounds dark chocolate is characterized by a praline, chocolate flavor with malty, nutty, and caramel notes, while the typical flavor of milk chocolate is sweet, milky, and honey-like with coconut notes [43] as shown in Tables 7-9.

TABLE 7. Variance analysis of flavor dark chocolate

\begin{tabular}{|c|c|c|c|c|c|c|}
\hline \multirow{2}{*}{$\begin{array}{l}\text { Sources of } \\
\text { diversity }\end{array}$} & \multirow{2}{*}{ df } & \multirow{2}{*}{ JK } & \multirow{2}{*}{ JKT } & \multirow{2}{*}{$\mathbf{F}_{\text {count }}$} & \multicolumn{2}{|c|}{$F_{\text {table }}$} \\
\hline & & & & & $5 \%$ & $1 \%$ \\
\hline Sample & 4 & 491,865 & 122,966 & 102,557 & 3.48 & 2.45 \\
\hline Panelist & 30 & 301,678 & 10,056 & 8,387 & 1.38 & 1.25 \\
\hline Error & 120 & 143,935 & 1,199 & & & \\
\hline Total & 154 & 937,478 & & & & \\
\hline
\end{tabular}

Legend: df (degree of freedom), JK (sum squares), JKT (mean squares), $\mathrm{F}_{\text {count }}$ (F calculate), $\mathrm{F}_{\text {table }}(\mathrm{F}$ table).

TABLE 8. F count value and $F$ table of Duncan multiple range test of $5 \%$ level

\begin{tabular}{lcccc}
\hline $\mathbf{P}$ & $\mathbf{2}$ & $\mathbf{3}$ & $\mathbf{4}$ & $\mathbf{5}$ \\
\hline Ranges & 2.77 & 2.92 & 3.02 & 3.09 \\
Least significant ranges (LSR) & 0.545 & 0.574 & 0.594 & 0.608 \\
\hline
\end{tabular}

TABLE 9. Comparison between treatments

\begin{tabular}{lccc}
\hline Sample & Average & LSR & Notes \\
\hline 231 & 4.83 & - & $\mathrm{a}$ \\
123 & 8.03 & 0.608 & $\mathrm{a}$ \\
132 & 7.22 & 0.545 & $\mathrm{~b}$ \\
312 & 7.19 & 0.594 & $\mathrm{c}$ \\
213 & 6.16 & 0.574 & $\mathrm{~d}$ \\
\hline
\end{tabular}

\section{Conclusion}

Dark chocolate products produced meet the criteria of healthy food because it has a high content of polyphenols and flavanoids. Dark chocolate formulation with a comparison of cocoa beans without fermentation and fermented cocoa beans (25\%: $75 \%$ ) has a better aroma and flavor and is more liked by consumers compared to other products; it can be seen from the viscosity value, melting point, lightness, hardness, and flavors of dark chocolate products that resemble commercial chocolate. This research can be useful in developing dark chocolate products that have an equivalent nutritional value with the value of taste, so that can be a reference for chocolate products that are worth the functional food. 


\section{References}

1. Pirman, Yusuf M, Utami M, Rahmawati, Alam S. Evaluasi sensori dan karakterisasi sifat fisikokimia minuman instan kaya polifenol dari biji kakao pilihan. Prosiding Seminar Hasil Penelitian. 2018, 1, 143-148. EVALUASI_SENSORI_DAN_KARAKTERISASI_SIFAT.pdf

2. Afoakwa EO, Paterson A, Fowler M, Ryan A. Flavor formation and character in cocoa and chocolate: a critical review. Critical Reviews in Food Science and Nutrition. 2008, 48, 840-857. https://doi.org/10.1080/10408390701719272.

3. Macías-Sánchez MD, Mantell C, Rodríguez M, Martínez de la Ossa E, Lubián LM, Montero O. Comparison of supercritical fluid and ultrasound-assisted extraction of carotenoids and chlorophyll a from Dunaliella salina. Talanta. 2009, 77(3), 948-952. https://doi.org/10.1016/j. talanta.2008.07.032

4. Martin MA, Goya L, Ramos S. Potential for preventive effects of cocoa and cocoa polyphenols in cancer. Food and Chemical Toxicology. 2013, 56, 336-351. https://doi.org/10.1016/j. fct.2013.02.020

5. Martín MA, Ramos S. Cocoa polyphenols in oxidative stress: potential health implications. Journal of Functional Foods. 2016, 274, 570-588. https://doi.org/10.1016/j.jff.2016.10.008

6. Putra Ganda GP, Wartini NM, Anggreni AAM. Characterization of polyphenol oxidase enzyme of cocoa beans (Theobroma cacao Linn.). Agritech. 2010. http://portalgaruda.fti.unissula.ac.id/ index.php?ref=browse $\&$ mod=viewjournal\&journal $=7837 \&$ issue $=\% 20 \mathrm{Vol} \% 2030, \% 20 \mathrm{No} \% 20$ 03\%20(2010)

7. Cruz JFM, Leite PB, Soares SE, Bispo E da S. Bioactive compounds in different cocoa (Theobroma cacao, L) cultivars during fermentation. Food Science Technology. 2015, 35(2), 279-284. https:// doi.org/10.1590/1678-457X.6541

8. Redovniković IR, Delonga K, Mazor S, Dragović-Uzelac V, Carić M, Vorkapić-Furač J. Polyphenolic content and composition and antioxidative activity of different cocoa liquors. Czech Journal of Food Sciences. 2009, 27(5), 330-337. https://doi.org/10.17221/119/2008-cjfs

9. Eskes B, Ahnert D, Assemat S, Seguine E. Evidence for the effect of the cocoa bean flavour environment during fermentation on the final flavour profile of cocoa liquor and chocolate. Ingenic. 2006. https://plantscience.psu.edu/research/labs/guiltinan/cacao-for-peace/research/ research-symposium-agenda-and-other-information/general-cacao-related-information/ ingenic-newsletters/eskes-et-al-ingenic-nl-12

10. Osakabe N, Yamagishi M, Sanbongi C, Natsume M, Takizawa T, Osawa T. The antioxidative substances in cacao liquor. Journal of Nutritional Science and Vitaminology (Tokyo). 1998, 44(2), 313-321. https://doi.org/10.3177/jnsv.44.313

11. Sanbongi C, Osakabe N, Natsume M, Takizawa T, Gomi S, Osawa T. Antioxidative polyphenols isolated from Theobroma cacao. Journal of Agricultural and Food Chemistry. 1998, 46(2), 454457. https://doi.org/10.1021/jf970575o

12. Torres-Moreno M, Torrescasana E, Salas-Salvadó J, Blanch C. Nutritional composition and fatty acids profile in cocoa beans and chocolates with different geographical origin and processing conditions. Food Chemistry. 2015, 166, 125-32. https://doi.org/10.1016/j.foodchem.2014.05.141.

13. Cambrai A, Marcic C, Morville S, Houer PS, Bindler F, Marchioni E. Differentiation of chocolates according to the cocoa's geographical origin using chemometrics. Journal of Agricultural and Food Chemistry. 2010, 58(3), 1478-1483. https://doi.org/10.1021/jf903471e

14. Marseglia A, Acquotti D, Consonni R, Cagliani LR, Palla G, Caligiani A. HR MAS 1H NMR and chemometrics as useful tool to assess the geographical origin of cocoa beans - comparison 
with HR 1H NMR. Food Research International. 2016, 85, 273-281. https://doi.org/10.1016/j. foodres.2016.05.001

15. Teye E, Huang X, Dai H, Chen Q. Rapid differentiation of Ghana cocoa beans by FT-NIR spectroscopy coupled with multivariate classification. Spectrochimica Acta Part A: Molecular and Biomolecular Spectroscopy. 2013, 183-189. DOI: 10.1016/j.saa.2013.05.063.

16. Marinova D, Ribarova F, Atanassova M. Total Phenolics and Total Flavonoids in Bulgarian Fruits and Vegetables. Journal of Chemical Technology and Metallurgy. 2005, 40(3), 255-260. https://dl.uctm.edu/journal/node/j2005-3/Marinova.pdf

17. Zhu K, Kanu PJ, Claver IP, Zhu K, Qian H, Zhou H. A method for evaluating Hunter whiteness of mixed powders. Advanced Powder Technology. 2009, 20(2), 123-126. https://doi.org/10.1016/j. apt.2008.04.001

18. Glicerina V, Balestra F, Dalla Rosa M, Romani S. Microstructural and rheological characteristics of dark, milk and white chocolate: a comparative study. Journal of Food Engineering. 2016, 169, 165-171. https://doi.org/10.1016/j.jfoodeng.2015.08.011

19. Gloria H, Sievert D. Changes in the physical state of sucrose during dark chocolate processing. Journal of Agricultural and Food Chemistry. 2001, 49(5), 2433-2436. https://doi.org/10.1021/ jf0008240

20. Afoakwa EO, Paterson A, Fowler M, Vieira J. Relationship between rheological, textural and melting properties of dark chocolate as influenced by particle size distribution and composition. European Food Research and Technology. 2008, 227(4), 1215-1223. https://doi.org/10.1007/ s00217-008-0839-5

21. Afoakwa EO. Processing effects on the rheological, textural and melting properties during chocolate manufacture. Chocolate Science and Technology. 2016. https://doi. org/10.1002/9781118913758.ch12

22. Afoakwa EO, Quao J, Takrama FS, Budu AS, Saalia FK. Changes in total polyphenols, o-diphenols and anthocyanin concentrations during fermentation of pulp pre-conditioned cocoa (Theobroma cacao) beans. International Food Research Journal. 2012, 19(3), 1-7. http://www.ifrj.upm.edu.my/19\%20(03)\%202012/(39)\%20IFRJ\%2019\%20(03)\%202012\%20 Emmanuel\%20Ghana.pdf

23. Nazaruddin R, Seng LK, Hassan O, Said M. Effect of pulp preconditioning on the content of polyphenols in cocoa beans (Theobroma cacao) during fermentation. Industrial Crops and Products. 2006, 24(1), 87-94. https://doi.org/10.1016/j.indcrop.2006.03.013

24. Misnawi A, Jinap S, Jamilah B, Nazamid S. Sensory properties of cocoa liquor as affected by polyphenol concentration and duration of roasting. Food Quality and Preference. 2004. https:// doi.org/10.1016/S0950-3293(03)00097-1

25. Serra Bonvehí J, Ventura Coll F. Evaluation of purine alkaloids and diketopiperazines contents in processed cocoa powder. European Food Research and Technology. 2000, 210(3), 189-195. https://doi.org/10.1007/PL00005510

26. Mellor DD, Sathyapalan T, Kilpatrick ES, Beckett S, Atkin SL. High-cocoa polyphenol-rich chocolate improves HDL cholesterol in Type 2 diabetes patients. Diabetic Medicine. 2010, 27(11), 1318-1321. https://doi.org/10.1111/j.1464-5491.2010.03108.x

27. Sathyapalan T, Beckett S, Rigby AS, Mellor DD, Atkin SL. High cocoa polyphenol rich chocolate may reduce the burden of the symptoms in chronic fatigue syndrome. Nutrition Journal. 2010, 9, 55. DOI: 10.1186/1475-2891-9-55.

28. Nurhayati R, Herawati ERN, Oktaviani B, Rachmawati ID. The effect of refining time to the antioxidant capacity, phenolic content, sensory and physical properties of dark chocolate 
couverture. IOP Conference Series: Earth and Environmental Science. 2019. https://doi. org/10.1088/1755-1315/251/1/012047

29. Munsell AH. Munsell soil color charts. Munsell Color Co. 2000. https://doi.org/10.1021/ ja1019063

30. Kirchhoff PM, Biehl B, Crone G. Peculiarity of the accumulation of free amino acids during cocoa fermentation. Food Chemistry. 1989, 31(4), 295-311. https://doi. org/10.1016/0308-8146(89)90071-X

31. Pandey KB, Rizvi SI. Plant polyphenols as dietary antioxidants in human health and disease. Oxidative Medicine and Cellular Longevity. 2009, 2(5), 270-278. https://doi.org/10.4161/ oxim.2.5.9498

32. Afoakwa EO, Paterson A, Fowler M, Vieira J. Comparison of rheological models for determining dark chocolate viscosity. International Journal of Food Science \& Technology. 2009, 44(1), 162 167. https://doi.org/10.1111/j.1365-2621.2008.01710.x

33. Camu N, De Winter T, Addo SK, Takrama JS, Bernaert H, De Vuyst L. Fermentation of cocoa beans: Influence of microbial activities and polyphenol concentrations on the flavour of chocolate. Journal of the Science of Food and Agriculture. 2008. https://doi.org/10.1002/jsfa.3349

34. Lefeber T, Papalexandratou Z, Gobert W, Camu N, De Vuyst L. On-farm implementation of a starter culture for improved cocoa bean fermentation and its influence on the flavour of chocolates produced thereof. Food Microbiology.2012, 30(2), 379-392. https://doi.org/10.1016/j. fm.2011.12.021

35. Beckett ST. Science of chocolate. 2008. https://doi.org/10.1039/9781847552143

36. Beckett ST. Traditional chocolate making. industrial chocolate manufacture and use, 4 th edn. 2009. https://doi.org/10.1002/9781444301588.ch1

37. Glicerina V, Balestra F, Dalla Rosa M, Romani S. Microstructural and rheological characteristics of dark, milk and white chocolate: a comparative study. Journal of Food Engineering. 2016, 169, 165-171. https://doi.org/10.1016/j.jfoodeng.2015.08.011

38. Svanberg L, Ahrné L, Lorén N, Windhab E. Effect of sugar, cocoa particles and lecithin on cocoa butter crystallisation in seeded and non-seeded chocolate model systems. Journal of Food Engineering. 2011, 104(1), 70-80. https://doi.org/10.1016/j.jfoodeng.2010.09.023

39. Lipp M, Anklam E. Review of cocoa butter and alternative fats for use in chocolate - part A. Compositional data. Food Chemistry. 1998, 62(1), 73-97. https://doi.org/10.1016/ S0308-8146(97)00160-X

40. Rothkopf I, Danzl W. Changes in chocolate crystallization are influenced by type and amount of introduced filling lipids. European Journal of Lipid Science and Technology. 2015, 117(11), 1714-1721. https://doi.org/10.1002/ejlt.201400552

41. Limbardo RP, Santoso H, Witono JR. The effect of coconut oil and palm oil as substituted oils to cocoa butter on chocolate bar texture and melting point. AIP Conference Proceedings. 2017, 1840(1). https://doi.org/10.1063/1.4982281

42. Bahari A, Akoh CC. Texture, rheology and fat bloom study of 'chocolates' made from cocoa butter equivalent synthesized from illipe butter and palm mid-fraction. LWT. 2018, 97, 349354. https://doi.org/10.1016/j.lwt.2018.07.013

43. Aprotosoaie AC, Luca SV, Miron A. Flavor chemistry of cocoa and cocoa products - an overview. Comprehensive Reviews in Food Science and Food Safety. 2016, 15(1), 73-91. https:// doi.org/10.1111/1541-4337.12180 